Published in final edited form as:

Org Lett. 2007 February 1; 9(3): 533-536. doi:10.1021/ol0629869.

\title{
Stereoselective Synthesis of the C(1)-C(19) Fragment of
}

\section{Tetrafibricin}

Ricardo Lira and William R. Roush

Departments of Chemistry and Biochemistry, Scripps Florida, Jupiter Florida 33458

\section{Abstract}<smiles>O=CCCOS(=O)(=O)c1ccccc1</smiles>

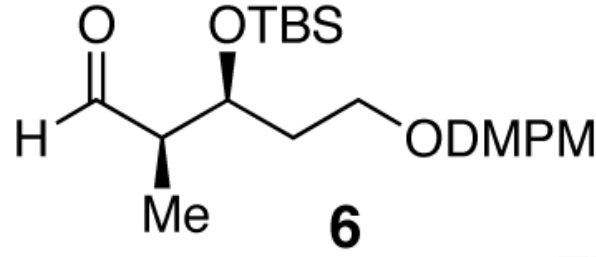

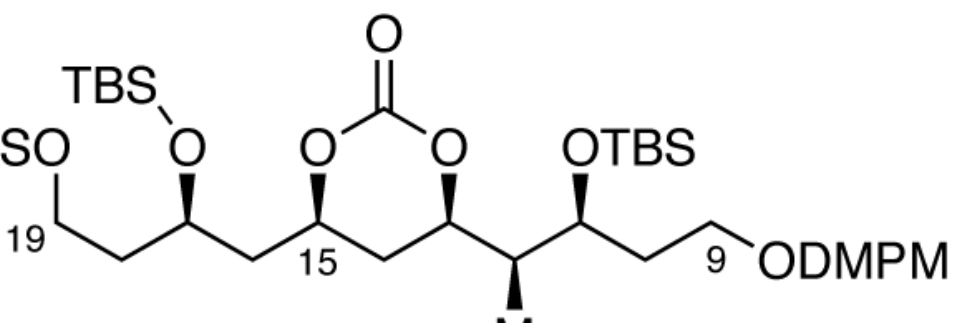

$5 \mathrm{Me}$

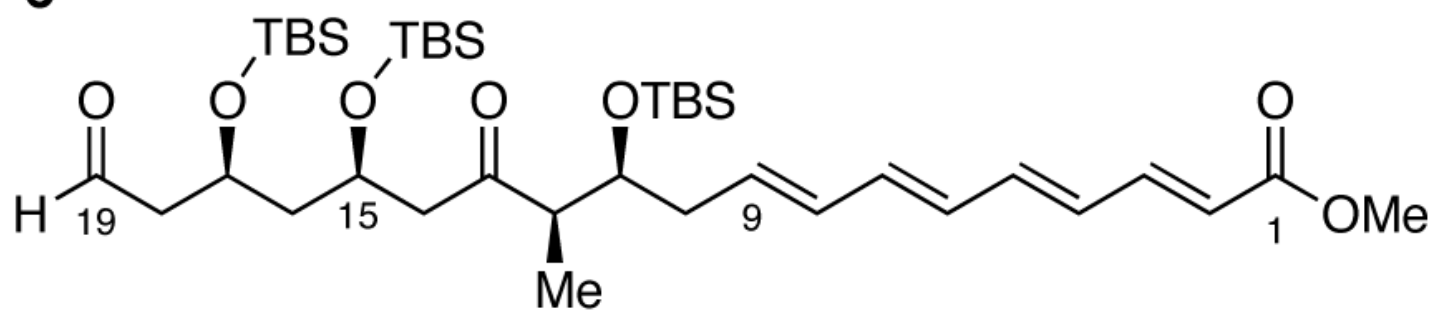

3

A stereoselective synthesis of the $\mathrm{C}(1)-\mathrm{C}(19)$ fragment of tetrafibricin has been accomplished via a highly diastereoselective double allylboration reaction of 6,7 , and 8 , and an iodonium-ion promoted urethane cyclization for the installation of the $\mathrm{C}(15)$ alkoxy function in 3 .

Tetrafibricin is a polyoxygenated fibrinogen receptor inhibitor, that was isolated in 1993 from the culture broth of Streptomyces neyagawaensis NR0577. ${ }^{1}$ Fibrinogen binding to the glycoprotein GPIIb/IIIa complex on the platelet surface plays a crucial role in platelet aggregation. ${ }^{2}$ The ability of tetrafibricin to block fibrinogen from binding to its glycoprotein receptor makes it a viable target for the potential therapeutic intervention of arterial thrombotic 
diseases such as coronary occlusion..$^{3,4}$ Kishi and co-workers recently assigned the stereochemistry of tetrafibricin (1) through the use of a NMR databatase method, supplemented by data obtained from NMR measurements in chiral solvents. ${ }^{5}$ The interesting biological properties and challenging structure, which includes eleven stereocenters of which ten are secondary hydroxyls arrayed as 1,3- and 1,5-diols, renders tetrafibricin an excellent target for synthetic study. Development of an an efficient, convergent synthesis of tetrafibricin (1) will facilitate structure activity relationship studies designed to probe its biological properties. To our knowledge, only Cossy has disclosed efforts towards the total synthesis of tetrafibricin. ${ }^{6}$ We report herein our initial synthetic studies on 1, culminating in an efficient synthesis of the $\mathrm{C}(1)-\mathrm{C}(19)$ fragment $\mathbf{3}$ via application of the double allylboration methodology developed in our laboratory. ${ }^{7}$

Our retrosynthetic analysis of tetrafibricin is outlined in Figure 1. We envisaged that tetrafibricin can be assembled from a late stage double allylboration sequence involving the coupling of the functionalized aldehydes $\mathbf{2}$ and $\mathbf{3}$ with bifunctional allylborane $4 .{ }^{7}$ It is expected that this reaction will provide the $\mathrm{C}(19)-\mathrm{C}(23)$ anti-1,5-diol unit of $\mathbf{1}$ with an embedded trans olefin in a single step. Aldehyde $\mathbf{3}$ would be assembled in turn from cyclic carbonate $\mathbf{5}$ through a Horner-Wadsworth-Emmons olefination sequence, followed by oxidation of the $\mathrm{C}$ (13) and C(19) alcohols. Further analysis of carbonate 5 suggests it can be accessed via a three component coupling of aldehydes $6^{8}$ and $7^{9}$ with bifunctional allylborane 8 , followed by installation of $\mathrm{C}(15)-\mathrm{OH}$.

The synthesis of the $\mathrm{C}(1)-\mathrm{C}(19)$ fragment $\mathbf{3}$ commenced with the construction of benzyl carbamate 13 (Scheme 1). Intially, we purused the synthesis of alcohol 12 via a one-pot double allylboration sequence followed by selective protection of the $\mathrm{C}(17)$ allylic alcohol. ${ }^{10}$

However, we were only able to achieve ca. $2: 1$ selectivity in protecting the allylic alcohol of the diol corresponding to $\mathbf{1 2}$. Therefore it proved advantageous to synthesize $\mathbf{1 2}$ via an interrupted, three-pot double allylboration sequence in order to differentiate the secondary $\mathrm{C}$ (17) and C(13) alcohols. ${ }^{11}$ Thus, treatment of aldehyde $7^{9}$ with the in situ generated bifunctional $(E)$-allylborane $8^{7}$ [derived from the hydroboration of allene $9^{7}$ with $\left({ }^{\mathrm{d}} \mathrm{Ipc}\right)_{2} \mathrm{BH}$ ], 12 followed by quenching with water, afforded $\beta$-hydroxy allylboronate $\mathbf{1 0}$ in $82 \%$ isolated yield. ${ }^{13}$ The resultant allylic alcohol was protected by treatment with TBSOTf and 2,6-lutidine to afford allylboronate $\mathbf{1 1}$ in $89 \%$ yield. Treatment of $\mathbf{1 1}$ with 1.1 equiv. of aldehyde $\mathbf{6}^{8}$ at 23 ${ }^{\circ} \mathrm{C}$ for $96 \mathrm{~h}$ proceeded in a matched fashion and provided homoallyl alcohol $\mathbf{1 2}$ in $73 \%$ yield as a 16:1 mixture of diastereomers. ${ }^{14}$ The homoallyl alcohol was then treated with benzyl isocyanate in toluene at $115{ }^{\circ} \mathrm{C}$ to provide key benzyl carbamate $\mathbf{1 3}$ in $85 \%$ yield.

Attention next focused on the diastereoselective installation of the $C(15)-\beta$ alkoxy group of fragment 3 via an iodonium-ion promoted urethane cyclization. Initial attempts to affect this cyclization by treatment of $\mathbf{1 3}$ with iodine monochloride in $\mathrm{CH}_{2} \mathrm{Cl}_{2}$ at $-78{ }^{\circ} \mathrm{C}^{15}$ afforded a mixture of the desired iodo carbonate $\mathbf{1 4}$ along with an inseparable furan side product $\mathbf{1 5}$ (Table 1, entry 1). This side product arises from a 5-exo type cyclization with concomitant deprotection of the TBDPS ether. We anticipated that use of a pyridine-ICl complex would slow the rate of the competing furan formation by moderating the reactivity of the iodonium ion. Accordingly, treatment of carbamate 13 with a preformed pyridine-ICl complex in $\mathrm{CH}_{2} \mathrm{Cl}_{2}$ at $-78{ }^{\circ} \mathrm{C}$ and warming to $23{ }^{\circ} \mathrm{C}$ provided a small amount of the targeted iodo carbonate 14 (17\%, entry 2$)$; however, more importantly, formation of the furan side product was completely suppresed. This observation prompted an investigation of NIS as the iodine source due to its stability and ease of handling. Gratifyingly, treatment of benzyl carbamate 13 in $\mathrm{CHCl}_{3}$ at $23{ }^{\circ} \mathrm{C}$ with NIS (added portionwise) effected a clean cyclization which provided carbonate $\mathbf{1 4}$ as the sole product in $70 \%$ yield and $>20: 1$ diastereoselectivity as judged by ${ }^{1} \mathrm{H}$ NMR analysis. ${ }^{16}$ 
Deiodination of $\mathbf{1 4}$ by treatment with $\mathrm{Et}_{3} \mathrm{~B}$ and $n-\mathrm{Bu}_{3} \mathrm{SnH}$ generated desired intermediate 5 in $88 \%$ yield. ${ }^{17}$ To verify the $\mathrm{C}(13)-\mathrm{C}(15)$ syn-stereochemistry, intermediate $\mathbf{5}$ was converted to acetonide analog 17 via a two step-sequence. ${ }^{18}{ }^{13} \mathrm{C}$ NMR analysis of the acetonide according to the Rychnovsky method ${ }^{18}$ confirmed the presence of a syn-1,3-diol relationship (see Supporting Information for details). Deprotection of the primary DMPM group of $\mathbf{5}$ with DDQ followed by Dess-Martin oxidation ${ }^{19}$ yielded sensitive aldehyde 16, the substrate for the subsequent Horner-Wadsworth-Emmons olefination with phosphonate 20.

Horner-Wadsworth-Emmons reagent 20 was synthesized starting with the $\mathrm{MnO}_{2}$ oxidation of the known alcohol $\mathbf{1 8}^{20}$ (Scheme 3). Subjection of the derived aldehyde to a Horner-

Wadsworth-Emmons ${ }^{21}$ olefination with triethyl phosphonoacetate afforded intermediate 19 in $70 \%$ yield. Deprotection of $\mathbf{1 9}$ by treatment with TBAF, followed by conversion of the allylic alcohol to the corresponding allylic bromide by treatment with $\mathrm{PBr}_{3}$ and pyridine, and then treatment of the allylic bromide with $\mathrm{P}(\mathrm{OEt})_{3}$ in refluxing toluene yielded the phosphonate coupling partner 20 in $76 \%$ yield over three steps. ${ }^{22}$ Gratifyingly, treatment of $\mathbf{2 0}$ with LHMDS followed by addition of a solution of aldehyde 16 at $-78^{\circ} \mathrm{C}$ with warming to $0{ }^{\circ} \mathrm{C}$ provided intermediate 21 in $77 \%$ yield. 23

Tetraenoate 21 contains all the carbon atoms of the C(1)-C(19) fragment 3 of tetrafibricin; all that remained to access keto-aldehyde 3 was to adjust the oxidation state of $\mathrm{C}(13)$ and $\mathrm{C}(19)$ alcohols. This was achieved by cleavage of the cyclic carbonate in $\mathbf{2 1}$, followed by a selective silylation of the less hindered $\mathrm{C}(15)-\mathrm{OH}$, which provided 22 with 10:1 regioselectivity. The crucial and selective deprotection of the C(19) TBDPS ether was accomplished in 55\% yield by using TAS-F in a DMF-AcOH solvent mixture. ${ }^{24}$ Finally, oxidation of the C(13)-C(19) diol with the Dess-Martin reagent ${ }^{19}$ provided the fully elaborated C(1)-C(19) fragment 3 of tetrafibricin.

In summary, we have accomplished an efficient and highly diastereoselective synthesis of $\mathbf{3}$ corresponding to the $\mathrm{C}(1)-\mathrm{C}(19)$ fragment of tetrafibricin. This synthesis proceeds in 13 steps from aldehyde 7 . The highlights of this synthesis include the highly diastereoselective interrupted double allylboration sequence used to prepare intermediate $\mathbf{1 2}$, the diastereoselective iodonium-ion promoted urethane cyclization of $\mathbf{1 3}$ for the installation of the syn-C(15) alkoxy group in 14, and a Horner-Wadsworth-Emmons olefination of $\mathbf{1 6}$ for introduction of the tetraenoate moeity. Further progress towards the completion of the total synthesis of tetrafibricin will be reported in due course.

\section{Supplementary Material}

Refer to Web version on PubMed Central for supplementary material.

\section{Acknowledgment}

This work was supported by the National Institutes of Health (GM 38436).

\section{References}

1. Kamiyama T, Umino T, Fujisaki N, Satoh T, Yamashita Y, Ohshima S, Watanabe J, Yokose K. J. Antibiot 1993;46:10392.

2. Kamiyama T, Itezono Y, Umino T, Satoh T, Nakayama N, Yokose K. J. Antibiot 1993;46:1047. [PubMed: 8360098]

3. Satoh T, Kouns WC, Yamashita Y, Kamiyama T, Steiner B. Biochem. Biophys. Res. Commun 1994;204:325. [PubMed: 7524499]

4. Satoh T, Yamashita Y, Kamiyama T, Arisawa M. Thromb. Res 1993;72:401. [PubMed: 8303683]

5. Kobayashi Y, Czechtizky W, Kishi Y. Org. Lett 2003;5:93. [PubMed: 12509899] 
6. BouzBouz S, Cossy J. Org. Lett 2004;6:3469. [PubMed: 15387525]

7. Flamme EM, Roush WR. J. Am. Chem. Soc 2002;124:13644. [PubMed: 12431072]

8. Prepared as reported for the synthesis of ent-6: Anderson OP, Barrett AGM, Edmunds JM, Hachiya S-I, Hendrix JA, Horita K, Malecha JW, Parkinson CJ, VanSickle A. Can. J. Chem 2001;79:1562.

9. Holmes AB, Hughes AB, Smithe AL. J. Chem. Soc. Perkin Trans. 1 1993:633.

10(a). Flamme EM, Roush WR. Beilstein J. Org. Chem 2005;1:7. [PubMed: 16542020] (b) Hicks JD, Flamme EM, Roush WR. Org. Lett 2005;7:5509. [PubMed: 16288543]

11. Flamme EM, Roush WR. Org. Lett 2005;7:1411. [PubMed: 15787519]

12. Brown HC, Singaram B. J. Org. Chem 1984;49:945.

13. Absolute stereochemistry of $\mathrm{C}(17)-\mathrm{OH}$ of $\mathbf{1 0}$ was assigned by Mosher ester analysis of an analog of 13; see Supporting Information for details.

14. The absolute stereochemistry of $\mathrm{C}(13)-\mathrm{OH}$ of $\mathbf{1 2}$ was assigned by ${ }^{1} \mathrm{H}$ NMR analysis of the corresponding Mosher esters; see Supporting Information for details.

15. Duan JJ-W, Smith AB III. J. Org. Chem 1993;58:3703.

16. These conditions have previously been employed for the cyclization of allylic trichloroacetimidates: Bongini A, Cardillo G, Orena M, Sandri S, Tomasini C. J. Org. Chem 1986;51:4905.

17. Miura K, Ichinose Y, Nozaki K, Fugami K, Oshima K, Utimoto K. Bull. Chem. Soc. Jpn 1989;62:143. 18. Rychnovsky SD, Rogers BN, Richarson TI. Acc. Chem. Res 1998;31:9.

19. Dess PB, Martin JC. J. Am. Chem. Soc 1978;100:300.

20. Berube G, Deslongchamps P. Can. J. Chem 1990;68:404.

21(a). Horner L, Hoffmann H, Wippel HG. Chem. Ber 1958;91:61. (b) Wadsworth WS, Emmons WD. J. Am. Chem. Soc 1961;83:1733. (c) Wadsworth WS. Org. Reactions 1977;25:1.

22. Mori Y, Asai M, Kawade J-I, Furukawa H. Tetrahedron 1995;51:5315.

23. Roush WR. J. Am. Chem. Soc 1980;102:1390.

24. Scheidt KA, Chen H, Follows BC, Chemler SR, Coffey DS, Roush WR. J. Org. Chem 1998;63:6436. 


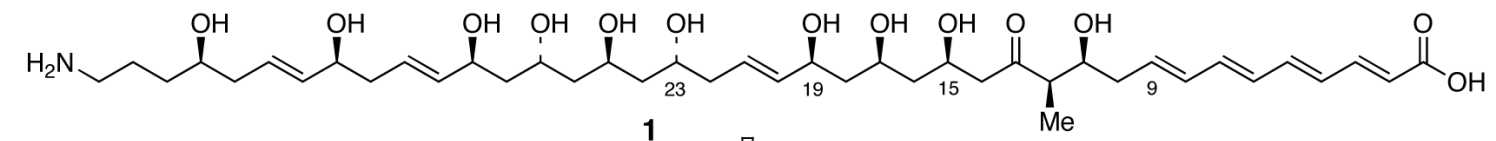

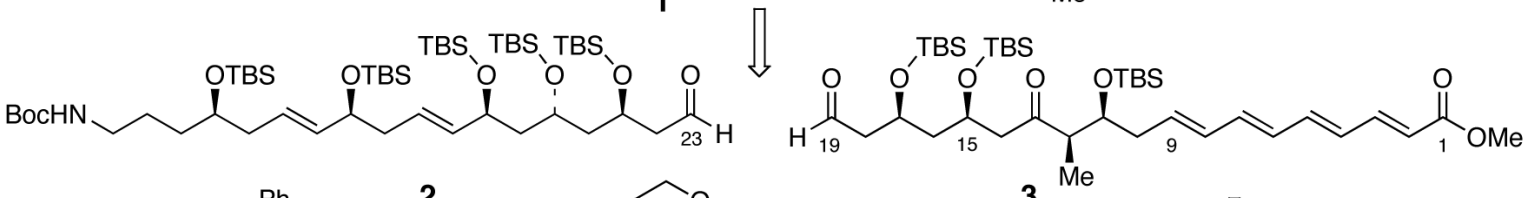

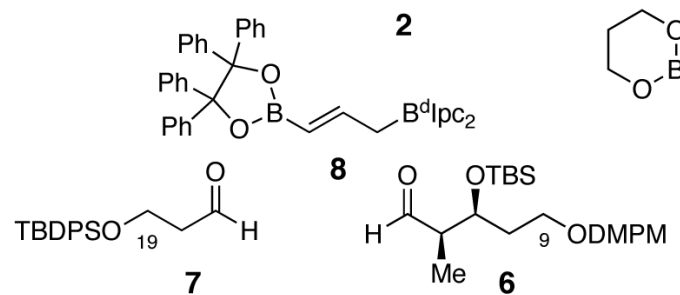

3
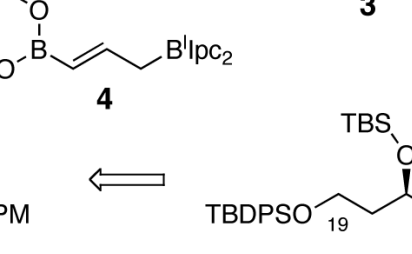<smiles>[CH]=C</smiles><smiles>C=CC=C</smiles>

Figure 1.

Tetrafibricin Retrosynthetic Analysis. 
<smiles>C=C=CB1OC(c2ccccc2)(c2ccccc2)C(c2ccccc2)(c2ccccc2)O1</smiles><smiles>[R]O[C@@H](CC=C)CCO[SbH2]</smiles>

TBSOTf 2,6-lutidine $\mathrm{CH}_{2} \mathrm{Cl}_{2}$

-78 to $0{ }^{\circ} \mathrm{C}$ $89 \%$<smiles>CCB1OC(C)(c2ccccc2)C(c2ccccc2)(c2ccccc2)O1</smiles>

\section{6. $\mathrm{CH}_{2} \mathrm{Cl}_{2}$}

$-78^{\circ} \mathrm{C}$ to $23^{\circ} \mathrm{C}$

$73 \%(16: 1 \mathrm{dr})$

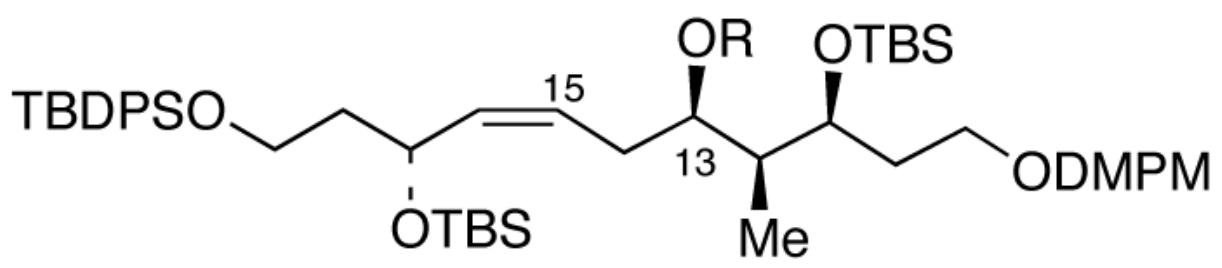

$$
\mathrm{R}=\mathrm{H}, 12 \quad \begin{gathered}
\mathrm{BnNCO} \\
\mathrm{PhMe} \\
115^{\circ} \mathrm{C} \\
85 \%
\end{gathered}
$$

Scheme 1.

Synthesis of Benzyl Carbamate $\mathbf{1 3}$ 


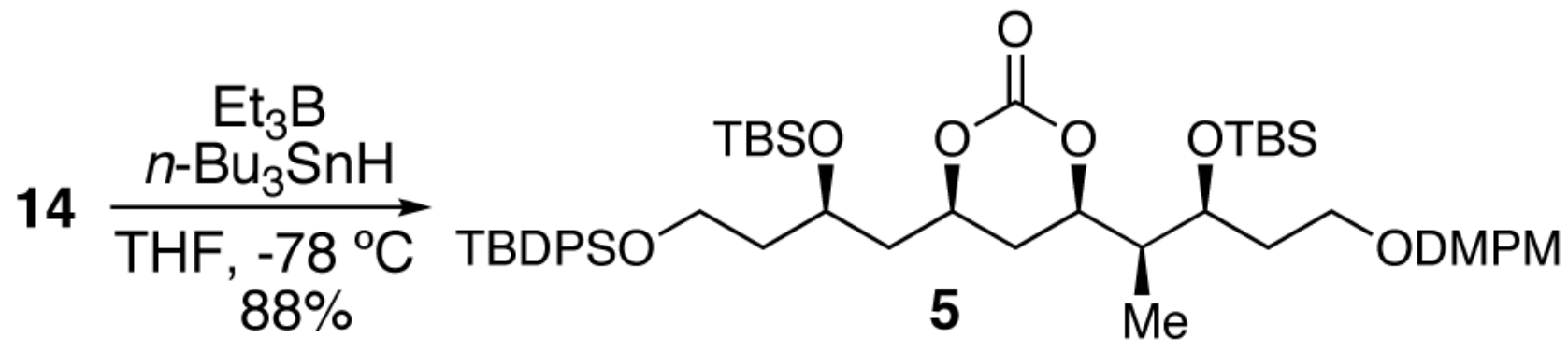

1) $\mathrm{DDQ}$

$\mathrm{CH}_{2} \mathrm{Cl}_{2}: \mathrm{pH} 7$ buffer $0^{\circ}$ to $23^{\circ} \mathrm{C}$

2) Dess-Martin

$\mathrm{CH}_{2} \mathrm{Cl}_{2}$

$0^{\circ}$ to $23{ }^{\circ} \mathrm{C}$

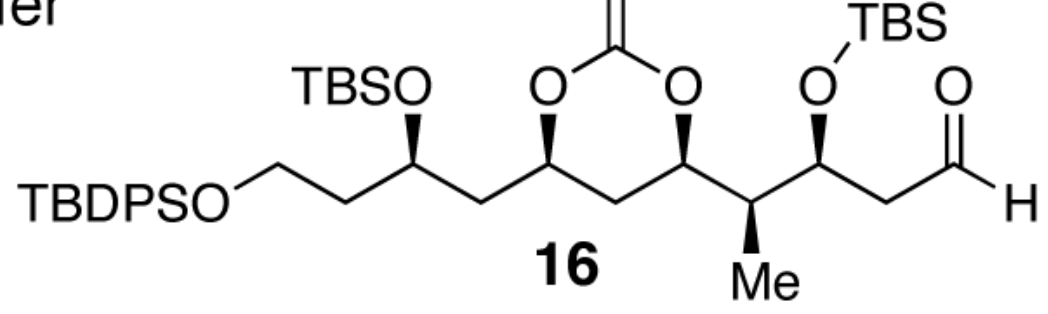
$49 \%$

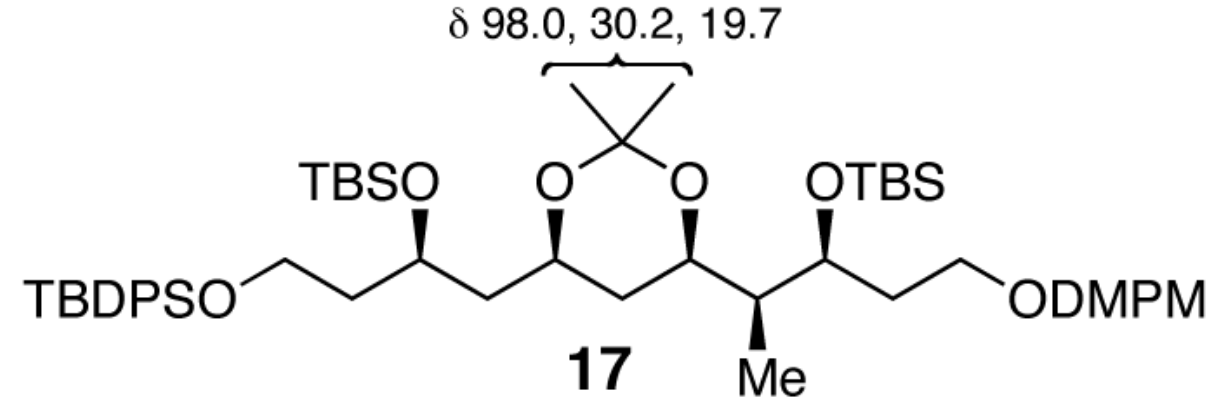

Scheme 2.

Synthesis of Aldehyde 16 


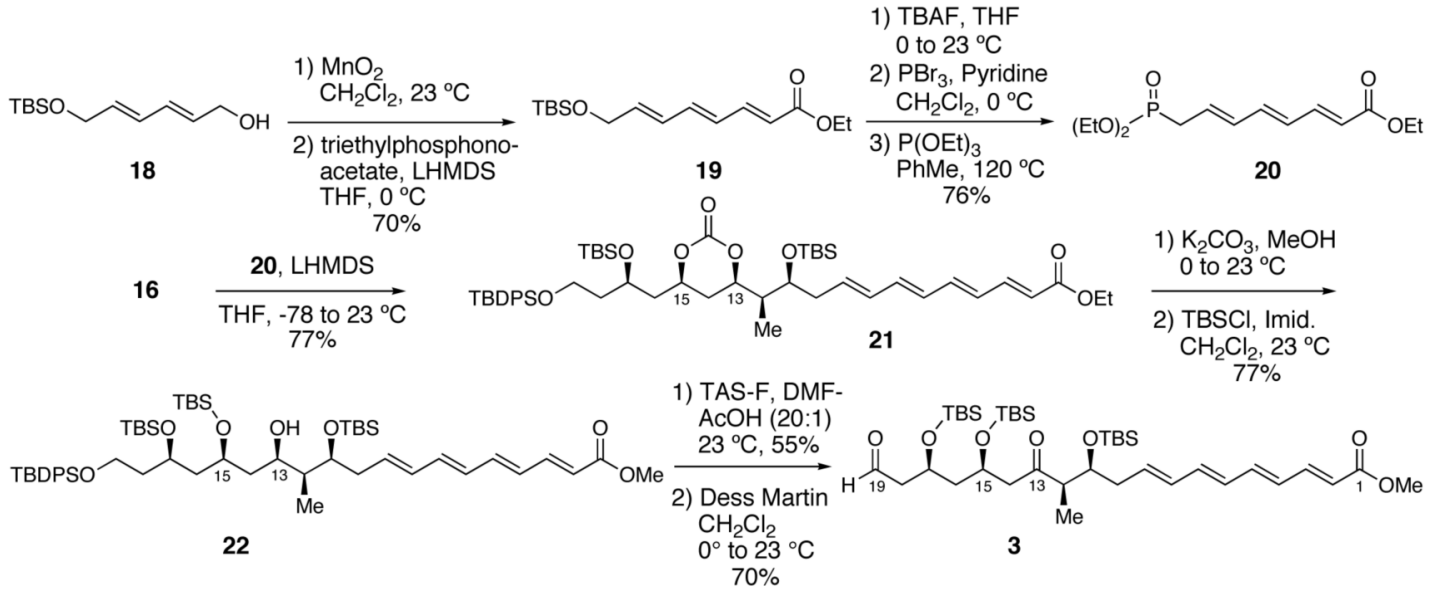

Scheme 3.

Completion of the Synthesis of the C(1)-C(19) Fragment 3 of Tetrafibricin 
Table 1

Installation of the C(15) Oxygen by an Iodonium Ion Promoted Urethane Cyclization

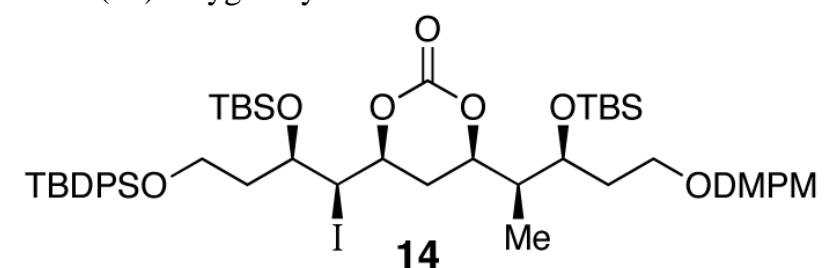

13

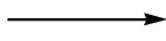

$+$

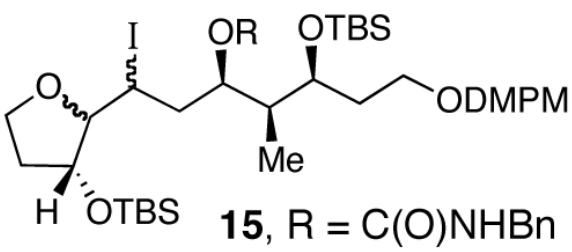

\begin{tabular}{cllc}
\hline entry & conditions & $\mathbf{1 3 : 1 4 : 1 5 ^ { a }}$ & yield of 14 (\%) \\
\hline 1 & $\mathrm{ICl} / \mathrm{CH}_{2} \mathrm{Cl}_{2},-78{ }^{\circ} \mathrm{C}$ & $0: 80: 20$ & 17 \\
2 & $\mathrm{ICl}-\mathrm{Pyr} / \mathrm{CH}_{2} \mathrm{Cl}_{2},-78$ to $0{ }^{\circ} \mathrm{C}$ & $50: 20: 0$ & 70 \\
3 & $\mathrm{NIS} / \mathrm{CHCl}_{3}, 0$ to $23{ }^{\circ} \mathrm{C}$ & $0: 100: 0$ & \\
\hline
\end{tabular}

${ }^{a}$ Ratio determined by ${ }^{1} \mathrm{H}$ NMR analysis 